Special Issue: Agricultural Productivity and Sustainability Improvement in Tropical Region

\title{
The Effect of Supplementation Lignolitic Probiotic in Rice Straw for Digestibility and Efficiency of Microbial Protein Synthesis using In Vitro Residual Gas Production
}

\author{
Indah Prihartini $^{1 *}$, Miftachi Ari ${ }^{2}$, Manar Fayiz Mousa Atoum ${ }^{3,4}$, Akhis Soleh Ismail ${ }^{1}$ and \\ Listiari Hendraningsih ${ }^{1}$
}

${ }^{1}$ Faculty of Agriculture and Animal Science, University of Mubammadiyah Malang, Jl. Raya Tlogomas 246 Malang 65144, Indonesia; ${ }^{2}$ Faculty of Animal Science, University of Brawijaya Malang, Jl. Veteran Malang 65145, Indonesia; ${ }^{3}$ Molecular Biology and Genetics, The Hashemite University, Zarqa PO Box 330127, 13133, Jordan; ${ }^{4}$ Faculty of Applied Health Sciences, The Hashemite University, Jordan.

Abstract | This study aimed to determine the effect of supplementation lignolitic probiotics in rice straw (Oryza sativa L.) on digestibility and efficiency of microbial protein synthesis using in vitro residual gas production and the optimal lignolitic probiotic in rice straw. The materials used were rice straw IR 64 cultivar and lignolitic TPG probiotic. The method used was Randomized Complete Block Design (RCBD) with four levels of treatments and three groups. In addition, a further test was conducted using Duncan's multiple range due to a significant difference. The treatments were rice straw added by probiotic level which consisted of ( $\mathrm{P} 0$ : 0 \%; P1: $0.5 \%$; P2: $1.0 \%$; P: $1.5 \%$ ). Also, the in-vitro gas production was observed at $2 \mathrm{~h}, 4 \mathrm{~h}, 8 \mathrm{~h}, 16 \mathrm{~h}, 24 \mathrm{~h}$, $36 \mathrm{~h}, 48 \mathrm{~h}, 72 \mathrm{~h}$, and $96 \mathrm{~h}$ incubation period for digestibility and efficiency of microbial protein synthesis using the in-vitro method. The result showed that treatment significantly affected $(P<0.05)$ gas production, digestibility, and efficiency of microbial protein synthesis (ESPM). The highest gas production, dry matter (DM), organic matter (OM) digestibility, and ESPM were $73.86 \mathrm{~mL} 500 \mathrm{mg}^{-1} \mathrm{DM} ; 43.56 \%$; $48.41 \%$, and $34.26 \mathrm{~g} \mathrm{~N} \mathrm{~kg}^{-1} \mathrm{FOM}$ (fermented organic matter) at $96 \mathrm{~h}$ incubation respectively. Therefore, probiotic lignolitic improves the digestibility of rice straw lignocelluse.

Received | August 19, 2021; Accepted | December 15, 2021; Published | December 30, 2021

*Correspondence | Indah Prihartini, Faculty of Agriculture and Animal Science, University of Muhammadiyah Malang, Jl. Raya Tlogomas 246 Malang 65144, Indonesia; Email: indahprihartini@gmail.com

Citation | Prihartini, I., M. Ari, M.F.M. Atoum, A.S. Ismail and L. Hendraningsih. 2021. The effect of supplementation lignolitic probiotic in rice straw for digestibility and efficiency of microbial protein synthesis using in-vitro residual gas production. Sarhad Journal of Agriculture, 37(Special issue 1): 136-143.

DOI | https://dx.doi.org/10.17582/journal.sja/2021.37.s1.136.143

Keywords | Improve ruminant feed, Lignocelluse, Lignochloritic bacteria, Rumen microbe, Waste as feed

\section{Introduction}

A gricultural waste is an alternative source of fiber for ruminants, specifically in the dry season, which is also cheap and has a high ability. Rice straw (Oryza sativa L.) is potential waste that Indonesian people have not widely used, but only a small portion of rice straw was utilized as an energy source for ruminants. Rice straw is a low-quality feed and limited utilization due to low protein (3.47\%) and the highest lignin (6.70\%) (Prihartini et al., 2009). He et al. (2019) also reported that the chemical composition of rice straw is dry matter $28.2 \%$, crude protein $8.16 \%$, true protein $6.65 \%$, nonprotein nitrogen $1.52 \%$, neutral detergent fiber $62.6 \%$, acid detergent fiber $33.5 \%$, and water-soluble 
carbohydrate $1.98 \%$. Furthermore, the compositions of elemental activated carbon of rice straw consist of Carbon $37.93 \%$, Hydrogen $6.19 \%$, Nitrogen $0.99 \%$, and Sulphur $2.07 \%$ (Saad et al., 2019)

Lignocellulose is an essential component of cell walls and forms the most significant portion of the carbon produced by plants (Prihartini et al., 2009). In the review, Guan et al. (2018) and Goodman (2020) reported that the major components of rice straw are cellulose, hemicellulose, lignin, and ash which $32.0 \%$ to $38.6 \%, 19.7 \%$ to $35.7 \%, 13.5 \%$ to $22.3 \%$, and $10 \%$ to $17 \%$, respectively. On the other hand, lignin of rice straw cell walls also contains silica surrounding the cell wall, and cellulose has changed from amorphous into a crystalline form. Hence, causing most carbs in the form of cellulose and hemicellulose to experirnce difficulty in digestion into energy (Prihartini et al., 2009). The form of silica $\left(\mathrm{SiO}_{2}\right)$ in the rice straw is crystalline, amorphous, and silica gel (Mirmohamadsadeghi and Karimi, 2020).

Rumen consists of bacteria, fungi, and protozoa, where most bacteria and fungi have the ability to degrade cellulose. However, rumen microbes have a limited ability to degrade lignin, while cellulose is naturally bound to the lignin, limiting the use of lignocellulose. To obtain microbial protein synthesis efficiency (ESPM) high rumen, microbes need $\mathrm{N}$ in the form of NPN (Non-Protein Nitrogen) and easy fermented carbohydrates for energy resources and minerals.

The study from Prihartini et al.(2009) stated that three isolates of lignochloritik have high growth potential, production, and enzyme activity, and specifically degrade lignin and organochlorine, grow well in the media are natural carriers of rice straw. However, the capability of microbial into lignin biodegradation is different, which is influenced by the composition and structure of lignin in plant cell walls and the ability lignolitic oxidative enzymes produced by microbes (Prihartini and Khotimah, 2011).

Lignochloritic bacterial isolates have the nature of facultative anaerobic bacteria that lives in both aerobic and anaerobic conditions and live inside or outside the cattle body. Bacterial growth is also high, hence, it was used as probiotics and introduced into the rumen to improve the digestibility of nutrients in the rumen and the ability to digest lignocellulose material (Prihartini and Khotimah, 2011).

Probiotics are live microbes in the livestock carrier medium is advantageous because it creates balance in the digestive tract microflora. In addition, these microbes help the integrity of intestinal mucosa, the process of metabolism, and boost immunity, thereby creating optimum conditions for feed digestion and conversion efficiency to facilitate the absorption of nutrients in the process of livestock (Arowo and He, 2018; Elghandour et al., 2015).

From the description above, it is necessary to test the digestion of rice straw lignocellulose with lignolitic probiotic supplementation before being applied to livestock directly. An alternative solution to determine the digestibility of feedstuffs is through digestibility experiments. The estimation method was in vitro digestibility. It is indirectly the principle replicate the atmosphere on ruminant digestion equipment, while the measurement of gas production in vitro fermentation of organic material describing associated with Metabolizable Energy (ME), while the Dry Matter Digestibility (DMD), Organic Matter Digestibility (OMD), and Efficiency of Microbial Protein Synthesis (ESPM) from the residual gas production is the actual dry matter or organic matter fermented in the rumen.

\section{Materials and Methods}

Study for gas production, dry matter digestibility analysis (DMD), organic matter digestibility (OMD), and efficiency of microbial protein synthesis (ESPM) from the residual gas production in vitro was conducted in the Nutrition Laboratory, whereas rumen fluid intake was conducted at the Field Laboratory, Sumber Sekar, Faculty of Animal Husbandry, Brawijaya University, Malang, East Java, Indonesia.

This study used rice straw IR 64 cultivar, Lignolitic probiotic, rumen fluid from fistulated dairy cattle, and materials to analyze gas production, digestibility, and ESPM in vitro. The method used in this study was Randomized Complete Block Design (RCBD) that consisted of four levels of treatments and three replications. The groupings are based on the time of rumen fluid collection. The treatments were followed:

$\mathrm{P} 0=$ rice straw (control)

$\mathrm{P} 1=$ rice straw $+0.5 \%$ probiotic levels of rice straw DM 
$\mathrm{P} 2=$ rice straw $+1.0 \%$ probiotic levels of rice straw $\mathrm{DM}$

$\mathrm{P} 3=$ rice straw $+1.5 \%$ probiotic levels of rice straw $\mathrm{DM}$

The dry matter measurement was carried out by heating the feed residue in an oven at $105^{\circ} \mathrm{C}$ for $24 \mathrm{~h}$, while the organic matter measurement was carried out by burning the residue in a $600{ }^{\circ} \mathrm{C}$ furnace for 4 h. DMD and OMD are calculated by Equation (1) and Equation (2) as follows:

$$
\begin{aligned}
& D M D(\%)=\frac{(a \times b)-(c \times d)-(e x f)}{a \times b} \times 100 \% \ldots \\
& O M D(\%)=\frac{(a \times g)-(c x d)-(e x f)}{a \times b \times g} \times 100 \% \ldots
\end{aligned}
$$

Which a is sample mass; $b$ is dry matter mass, $\mathrm{c}$ is residue mass, $\mathrm{d}$ is a dry matter of residue, $\mathrm{e}$ is blank mass, $f$ is a dry matter of blank mass, and $g$ is an organic matter of sample.

Methods for measuring gas production in vitro were used to identify residues incubation or fermentation products such as microbial biomass, VFA, and gas volume. Gas production measurements were carried out 11 times, namely at the incubation period of $2 \mathrm{~h}$, 4 h, 8 h, 12 h, 16 h, 24 h, 36 h, 48 h, 72 h, and 96 h. Furthermore, estimation of microbial biomass production was conducted based on the residual degraded pseudo (apparent digestible) were reduced with pure inert residues (true digestible) treatment and resulted in Neutral Detergent Solution (NDS) (Blummel et al., 1997). This method was also carried out by Yogi et al. (2017).

All of the data were analyzed by One Way ANOVA of CRD, followed by Duncan Multiple Range Test for testing the significant level at $5 \%$ (Adinurani, 2016). The data obtained were statistically analyzed using SPSS software version 21.0 (SPSS, 2012).

\section{Results and Discussion}

\section{In Vitro Gas Production}

The production of in vitro gas resulted from the fermentation process in the rumen and describes the number of $\mathrm{OM}$ digested in the rumen. The amount of gas released when the feed material by in vitro incubated in rumen fluid was closely linked to the digestibility of feed. Therefore, periodic measurement of gas production during the $96 \mathrm{~h}$ was performed to determine the amount of gas produced at a certain incubation time $(2 \mathrm{~h}, 4 \mathrm{~h}, 8 \mathrm{~h}, 12 \mathrm{~h}, 16 \mathrm{~h}, 24 \mathrm{~h}, 36 \mathrm{~h}$, $48 \mathrm{~h}, 72 \mathrm{~h}$, and $96 \mathrm{~h}$ ). The results of in vitro gas production are presented in Table 1 . Meanwhile, the graphic of the relation between incubation time with gas production during the $96 \mathrm{~h}$ is shown in Figure 1.

The results of the variant analysis showed that lignolitic probiotic supplementation had a significant effect $(P<0.05)$ on in vitro gas production at an incubation time of $2 \mathrm{~h}$ and $4 \mathrm{~h}$. At the incubation time of $8 \mathrm{~h}$, the effect was very significant $(P<0.01)$ and at the incubation time of more than $8 \mathrm{~h}$ had no significant impact $(P>0.05)$. The length of the incubation time of $2 \mathrm{~h}$ and $4 \mathrm{~h}$ indicates that the highest gas production is present in P3 (1.5\% lignolitic probiotic supplementation), which is not different from $\mathrm{P} 1$ ( $0.5 \%$ lignolitic probiotic supplementation) and P2 (1\% lignolitic probiotic supplementation). The lowest gas production is in $\mathrm{P} 0(0 \%$ lignolitic probiotic supplementation), unlike $\mathrm{P} 1$. An incubation period of $8 \mathrm{~h}$ shows that the highest gas production is in $\mathrm{P} 3$, which is not different from P2. Furthermore, the lowest gas production is in $\mathrm{P} 0$, which is not different from P1.

The level of lignolitic probiotics increases the value of gas production, indicating that the probiotic lignolitic affects fermentation in the rumen fluid. This is because lignolitik bacteria are able to degrade lignin which becomes the cell wall of rice straw, hence, cellulose and

\begin{tabular}{|c|c|c|c|c|c|c|c|c|c|}
\hline \multirow[t]{2}{*}{ Treatment } & \multicolumn{9}{|c|}{ gas production $\left(\mathrm{mL} \mathrm{mg} \mathrm{m}^{-1} \mathrm{DM}\right)$ on the hour incubation period } \\
\hline & 2 & 4 & 8 & 16 & 24 & 36 & 48 & 72 & 96 \\
\hline $\mathrm{P}_{0}$ & $0.75 \pm 0.25^{b}$ & $2.23 \pm 0.38^{\mathrm{b}}$ & $3.73 \pm 0.24^{c}$ & $9.05 \pm 2.00$ & $19.09 \pm 5.23$ & $33.78 \pm 4.63$ & $44.68 \pm 3.23$ & $57.14 \pm 3.49$ & $67.38 \pm 5.04$ \\
\hline $\mathrm{P}_{1}$ & $1.08 \pm 0.27^{\mathrm{ab}}$ & $2.41 \pm 0.15^{\mathrm{ab}}$ & $4.32 \pm 0.38^{\mathrm{bc}}$ & $10.19 \pm 3.09$ & $20.97 \pm 6.03$ & $34.92 \pm 4.59$ & $45.96 \pm 3.19$ & $59.70 \pm 4.99$ & $69.48 \pm 5.31$ \\
\hline $\mathrm{P}_{2}$ & $1.33 \pm 0.28^{\mathrm{a}}$ & $2.99 \pm 0.49^{a}$ & $5.23 \pm 0.65^{\mathrm{ab}}$ & $10.96 \pm 3.11$ & $21.74 \pm 5.32$ & $36.71 \pm 4.57$ & $47.33 \pm 3.13$ & $62.33 \pm 6.63$ & $71.67 \pm 6.12$ \\
\hline $\mathrm{P}_{3}$ & $1.58 \pm 0.38^{\mathrm{a}}$ & $3.32 \pm 0.76^{\mathrm{a}}$ & $5.73 \pm 0.65^{\mathrm{a}}$ & $12.05 \pm 2.88$ & $23.38 \pm 5.14$ & $38.05 \pm 4.48$ & $48.93 \pm 3.97$ & $62.92 \pm 5.05$ & $73.86 \pm 6.28$ \\
\hline $\mathrm{P}$-value & 0.043 & 0.035 & 0.006 & 0.626 & 0.810 & 0.683 & 0.496 & 0.532 & 0.569 \\
\hline
\end{tabular}

Table 1: Effect of lignolitic probiotic supplementation in rice straw on in vitro gas production.

Note: ${ }^{a, b, c}$ superscript in the same column indicate significant difference $(P<0.05)$. 


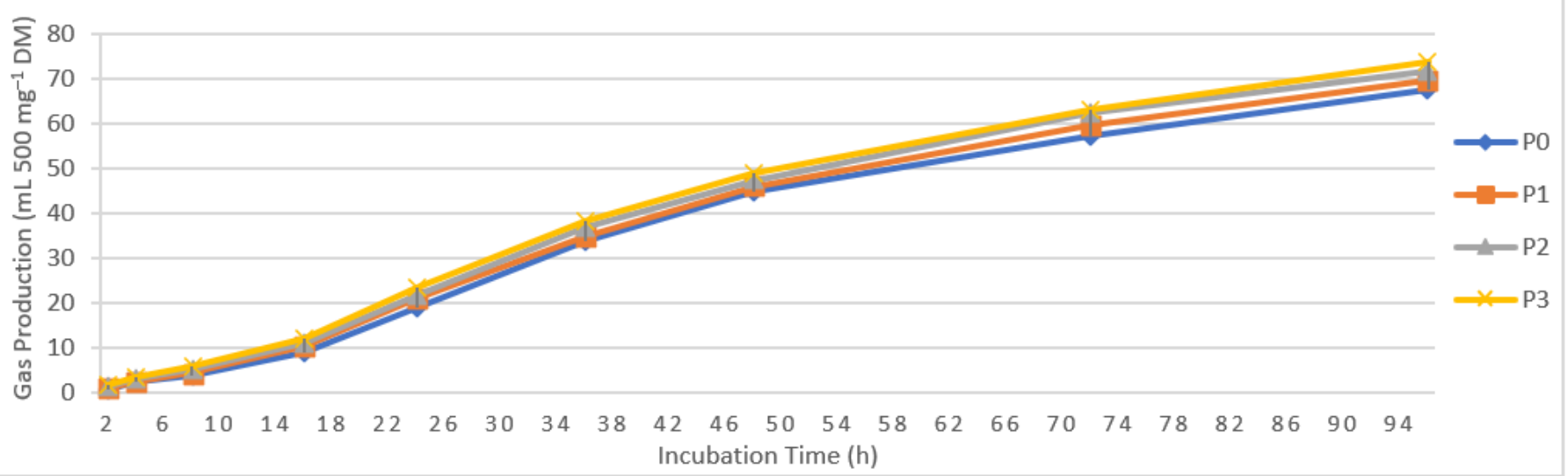

Figure 1: Graphic of the relation between incubation time with gas production.

hemicellulose were utilized by rumen microbes optimally (Prihartini and Hariska, 2019). While P0 only use rumen bacteria, which is not able to degrade lignin of rice straw, hence, cellulose and hemicellulose cannot be utilized by rumen microbes optimally. On an incubation period of more than $8 \mathrm{~h}$, lignolitic probiotic supplementation did not affect in vitro gas production. This is considered because free cellulose and hemicellulose are fermented into VFA and are used for microbial protein synthesis, such as presented in Table 3, FOM and ESPM increase with increasing probiotic levels). Izzudin et al. (2018) state that the gas produced results from the fermentation of feed, specifically organic materials, into the VFA (Volatile Fatty Acids) as an energy source in livestock are carried by the animal. This result is in line with the experiment of (Rabelo et al., 2017) that using Lactobacillus bunchneri as a probiotic increases the gas production in the rumen. Furthermore, Hassan et al. (2020) reported that using probiotics by feed enhances the gas production in the rumen.

The Figure 1 showed that gas production is high in anaerobic condition during $96 \mathrm{~h}$. This identified that increasing incubation period affected gas production enhancement. The increase due to the probiotic lignolitic does not antagonize the rumen, but it digests other materials. Therefore, the addition of probiotics in feed rice straw with lignin, cellulose, and hemicellulose is expected to be easily digestible. As explained above, that probiotic lignolitic degrade lignin well (Prihartini et al.,2009), hence, the nutrition of rice straw was degraded by rumen microbial, which is why gas production is high. This is also in line as Shah et al. (2018) stated that the Ligninolytic Bacillus sp. strains break down the lignin structure on the rice straw.

\section{Residues Digestibility of In Vitro Gas Production}

Anaerobic rumen microbe that is able to digest the feed material into the rumen becomes intermediated metabolites that were absorbed, utilized by microbes for metabolic processes in the body. The ability of livestock to use or ingestion of fiber depends on the action of microbes discovered in the digestive tract. Microbial activity degrades raw fiber into organic acids such as VFA, i.e., acetic acid, propionic acid, and butyric acid. The average of DMD and OMD and in vitro gas production at $96 \mathrm{~h}$ incubation period is presented in Table 2.

Table 2: Effect of lignolitic probiotic supplementation in rice straw on DM and OM in vitro gas production on $96 \mathrm{~h}$ incubation.

$\begin{array}{lll}\text { Treatment } & \text { Digestibility (\%) } \\ & \mathrm{DM} & \text { OM } \\ \mathrm{P}_{0} & 33.80 \pm 0.53^{\mathrm{d}} & 37.56 \pm 1.10^{\mathrm{d}} \\ \mathrm{P}_{1} & 35.95 \pm 0.50^{\mathrm{c}} & 39.93 \pm 0.55^{\mathrm{c}} \\ \mathrm{P}_{2} & 40.17 \pm 0.16^{\mathrm{b}} & 45.09 \pm 0.70^{\mathrm{b}} \\ \mathrm{P}_{3} & 43.56 \pm 0.76^{\mathrm{a}} & 48.41 \pm 0.27^{\mathrm{a}} \\ \mathrm{P} \text {-value } & 0.000 & 0.000\end{array}$

Note: ${ }^{a, b, c, d}$ superscript in the same column indicate significant difference $(P<0.05)$.

This experiment showed that lignolitic probiotic supplementation in rice straw in vitro with a $96 \mathrm{~h}$ incubation period had a very significant difference $(P<0.01)$ on dry materials and organic matter digestibility. The higher the dose of lignolitic probiotics, the higher the digested levels of dry matter (DM) and organic matter (OM). The highest dry and organic digestibility levels were discovered in $\mathrm{P} 3$, followed by P2, P1, and lowest in P0 (0\% of lignolytic probiotic supplementation). 
Prihartini and Khotimah (2011) reported that lignolitic bacteria have high-potential probiotics on growth, microbial, and enzyme activity production and degrade lignin. Probiotics also increases the population and activity of cellulolytic bacteria in the rumen. The enzyme produced by lignolitic probiotics is the enzyme laccase. Laccase is an oxidizing enzyme, which was first played in the process of degradation (Prihartini and Khotimah, 2011) and an extracellular enzyme that contains protein and minerals $\mathrm{Cu}$. This enzyme reduces oxygen to water and simultaneously forms a one-electron oxidizing aromatic variety. This enzyme has the ability to oxidize lignin with phenol subunits, but with the addition of a mediator, the subunit enzyme cannot oxidize phenol (Disale and Dixit, 2020).

Degradation of lignin in the rumen is very limited, and only a small portion of the rumen microbial compound transform, not condensed lignin. However, the presence of laccase enzyme in the probiotic lignolitic allowed the enzyme to break the bond of lignocellulose in the rumen, which increases digestibility into DM, and $\mathrm{OM}$ was material fermented in the rumen.

Lignolitic probiotics have a high potential to degrade lignin and low potential in degrading cellulose, thereby providing easily degraded products by rumen microbes. Microbial fermentation in the rumen, specifically in degrading fiber fraction, is determined by the production and activity of cellulolytic enzymes. A very influential factor is the availability of nutrients for microbial synthesis, which indicates the potential for higher rumen degradable due to the rumen environment conducive to the activity of rumen fermentation which leads to the DM degradation rate increased. This is because the addition of probiotics led to more stable rumen conditions and anaerobic, which led to the growth and development of the bacteria. Thus, the digestibility of feed substances, specifically dietary fiber digestibility, is increased. Astuti et al. (2018) stated that from all kinds of microbes, bacteria are the digestive extensively in the rumen. On the other hand, probiotics also enhance the intestinal architecture and immunomodulatory processes in a symbiotic and beneficial way (E1-Tawab et al., 2016; Raabis et al., 2019). This indicates the higher the dose of lignolitic probiotic supplementation, the higher digested levels of DM and OM.

\section{The efficiency of microbial protein synthesis}

Dietary nucleotides had no significant measurement of microbial protein synthesis in their role to provide protein for the microbes. Synthesis of microbial protein is affected by the rate of solving the Nitrogen $(\mathrm{N})$ feed, rate of absorption of ammonia, rate of the feed material flow will exit the rumen microbial amino acid requirement, and the type of rumen fermentation (Lopez and Dominguez-Ordonez, 2019; El-Nagar et al., 2019). This causes the NDS solution to digest all the microbes and plant cell walls, leaving residues that cannot be digested.

Based on Table 3, it could be analyzed that the addition of the probiotic against the value ESPM very significantly $(P<0.01)$. Thus, the value ESPM increased with the growing use of probiotics in rice straw because the feed containing the crude protein treatment was higher than the control diet to contribute $\mathrm{N}$ to microbial protein synthesis.

Table 3: The effect of lignolitic probiotic supplementation in rice straw on gas production, ESPM and FOM $96 \mathrm{~b}$ incubation.

$\begin{array}{llll}\text { Treatment } & \begin{array}{l}\text { Gas production } \\ \left(\mathbf{m L} \mathbf{5 0 0} \mathbf{~ m g}^{-1} \mathbf{B K}\right)\end{array} & \text { FOM }(\mathbf{g}) & \begin{array}{l}\text { ESPM (g N } \\ \left.\mathbf{k g}^{-1} \mathbf{F O M}\right)\end{array} \\ \mathrm{P}_{0} & 67.38 \pm 5.04 & 156.92 \pm 2.79^{\mathrm{d}} & 10.95 \pm 0.20^{\mathrm{d}} \\ \mathrm{P}_{1} & 69.48 \pm 5.31 & 166.17 \pm 2.24^{\mathrm{c}} & 19.03 \pm 0.39^{\mathrm{c}} \\ \mathrm{P}_{2} & 71.67 \pm 6.12 & 187.43 \pm 2.60^{\mathrm{b}} & 27.48 \pm 0.31^{\mathrm{b}} \\ \mathrm{P}_{3} & 73.86 \pm 6.28 & 202.53 \pm 2.73^{\mathrm{a}} & 34.26 \pm 0.43^{\mathrm{a}} \\ \mathrm{P} \text {-value } & 0.569 & 0.000 & 0.000\end{array}$

Note: ${ }^{a, b, s, d}$ superscript in the same column indicate significant difference $(P<0.05)$.

The lowest values discovered in P0 ESPM, i.e., 10.95 g $\mathrm{N} \mathrm{kg}^{-1} \mathrm{FOM}$, presumably because this rice straw is a source of fiber that is not easily digested in the rumen to VFA and gas, causing its low ESPM values, whereas the highest values discovered on the P3 ESPM, i.e., $34.26 \mathrm{~g} \mathrm{~N} \mathrm{~kg}^{-1} \mathrm{FOM}$. This fact indicates a balance of VFA production as an energy source and $\mathrm{NH}_{3}$, which was used for microbial protein synthesis. High bacterial biomass was influenced by probiotics lignolitik, which increases the microbial population needed to produce bacterial growth factors such as malic acid and increase $\mathrm{pH}$ stability that supports the growth of rumen cellulolytic bacteria (Prihartini et al., 2009). Microbial protein synthesis accounted for $59 \%$ of amino acids in the small intestine than amino acids that are not degraded to amino acids to satisfy the needs of livestock to produce faster. 
Microbial protein production was straight with activity and fermentation products, particularly $\mathrm{NH}_{3}$ and VFA rumen. Based on Table 3, ESPM production value is proportional to the study of Prihartini and Hariska (2019), namely the value of $\mathrm{NH}_{3}$ and VFA on feed treated with rice straw was added lignolitic probiotic increase than the control diet. There was a relationship of mutual benefit between the rumen microbial population and the digestibility of microbial protein production of nutrients in the rumen. Increasing rumen microbial population with high activity causes more nutrients to be digested. In contrast, the results of rumen digestion or fermentation products such as $\mathrm{NH}_{3}$ and VFA as an input for the formation of body cells which in turn ensures microbial growth and activity of microbes themselves (Lopez and Dominguez-Ordonez, 2019).

The addition of lignolitic probiotics improves digestibility nutrients which means the protein contained in feed ingredients will also rise. It is characterized by increasing the concentration of rumen $\mathrm{NH}_{3}$ further positive impacts on microbial protein production. As stated by Prihartini et al.(2009), because the rumen microbes cannot use amino acids directly, feed protein will be degraded further into the rumen $\mathrm{NH}_{3}$ and will use these as a source of nitrogen for synthesis body cells. Increased rumen microbial protein production means the supply of protein was used to host productivity (livestock).

\section{Conclusions and Recommendations}

This study concludes that lignolitic probiotic supplementation may improve rice straw digestion characterized by increased gas production in vitro at an incubation length of $2 \mathrm{~h}, 4 \mathrm{~h}$, and $8 \mathrm{~h}$ of incubation. In addition, lignolitic probiotic supplementation may also improve the digestibility of dry ingredients, organic matter, FOM, and ESPM of rice straw.

\section{Novelty Statement}

The novelty of this study is an ability of lignolitic probiotic high lignin degraded in an aerobic condition show with (i) increased gas production, (ii) increased dry matter and organic matter digestibility, (iii) increased efficiency of protein microbial synthesis feed based on rice straw on in vitro residual gas production test.

\section{Author's Contribution}

IP: Conceptualized and designed the study, elaborated the intellectual content, and performed the literature search, data acquisition, statistical analysis, manucript preparation, and manuscript revision.

MA: Carried out experimental studies and manuscript reviews.

MFMA: Elaborated the intellectual content, performed literature search, data manuscript review and guarantor.

ASI and LH: Reviewed manuscript.

All authors read and approved the final manuscript

Conflict of interest

The authors have declared no conflict of interest

\section{References}

Adinurani, P.G. 2016. Design and analysis of agro trial data: Manual and SPSS. Plantaxia, Yogyakarta, Indonesia.

Arowo, M.A. and J. He. 2018. Use of probiotics and botanical extracts to improve ruminant production in the tropics: A review. Anim. Nutr., 4(3): 241-249. https://doi.org/10.1016/j. aninu.2018.04.010

Astuti, W.D., K.G. Wiryawan, E. Wina, Y. Widyastuti, S. Suharti and R. Ridwan. 2018. Effect of selected Lactobacillus plantarum as probiotic on in vitro ruminal fermentation and microbial population. Pak. J. Nutr., 17(3) : 131139. https://doi.org/10.3923/ pjn.2018.131.139

Blummel, B.Y.M., H. Steingas and K. Becker. 1997. The relationship between in vitro gas production, in vitro microbial biomass yield and $15 \mathrm{n}$ incorporation and its implication for the prediction of voluntary feed intake of roughages. Br. J. Nutr., 77(6): 911921. https:// doi.org/10.1079/BJN19970089

Disale, S.N. and P.P. Dixit. 2020. Screening, isolation and biochemical characterization of laccase producing bacteria from raigad distric soil. Int. J. Sci., Res. 9 (1): 37-39.

Elghandour, M.M.Y., A.Z.M. Salem, J.S.M. Casteneda, L.M. Camacho, A.E. Kholif, and J.C.V. Chagoyan. 2015. Direct-fed microbes: A tool for improving the utilization of low quality roughages in ruminants. J. Integr. Agric., 14(3): 526-533. https://doi.org/10.1016/S2095- 


\section{9(14)60834-0}

El-Nagar, S.E., A.R. Shemies, G.F. Gouda, M.S. El-Garhi, H.M. Ebeid, H.H. Azzas, R.M.A. Abdelgawad, S.Z. Mona and N.E. Bourdeny. 2019. In vitro evaluation of probiotic bacteria supplementation of ruminant ration. Arab Uni. J. Agric. Sci., 27 (1) Article 31: 339-345. https://doi.org/10.21608/ajs.2019.43531

El-Tawab, M.M.A., I.M.I. Youssef, H.A. Bakr, G.C. Fthenakis and N.D. Giadinis. 2016. Role of probiotics in nutrition and health of small ruminants. Pol. J. Vet. Sci., 19(4): 893-906. https://doi.org/10.1515/pjvs-2016-0114

Goodman, B.A. 2020. Utilization of waste straw and husks from rice production: A review. J. Bioresour. Bioprod., 5(3): 143-162. https://doi. org/10.1016/j.jobab.2020.07.001

Guan, R., L., Xiuji, A.C. Wachemo, H. Yuan,Y. Liu, D. Zou, X. Zuo and J. Gu. 2018. Enhancing anaerobic digestion performance and degradation of lignocellulosic components of rice straw by combined biological and chemical pretreatment. Sci. Total Environ., 637-638: 9-17. https://doi.org/10.1016/j. scitotenv.2018.04.366

Hassan, A., H. Gado, U.Y.Anele, M.A.M.Berasain, A.Z.M. Salem. 2020. Influence of dietary probiotic inclusion on growth performance, nutrient utilization, ruminal fermentation activities and methane production in growing lambs. Anim. Biotechnol., 31(4): 1-8. https:// doi.org/10.1080/10495398.2019.1604380

He, L., W. Zhou,Y. Xing, R. Pian, X. Chen and Q. Zhang. 2019. Improving the quality of rice straw silage with Moringa oleifera leaves and propionic acid: fermentation, nutrition, aerobic stability and microbial communities. Bioresour. Technol., 299: 122579. https://doi. org/10.1016/j.biortech.2019.122579

Izzudin, W.I, T.C. Loh, A.A. Samsudin, H.L. Foo. 2018. In vitro study of postbiotics from Lactobacillus plantarum RG14 on rumen fermentation and microbial population. R. Bras. Zootec., 47 (e20170255): 1-7. https:// doi.org/10.1590/rbz4720170255

Lopez, E.C. and M.G. Dominguez-Ordenez. 2019. Factor affecting the ruminal microbial composition and methods to determine microbial protein yield yeview. Rev. Mex. Cienc. Pecu., 10(1):120-148. https://doi. org/10.22319/rmcp.v10i1.4547
Mirmohamadsadeghi, S. and K. Karimi. 2020.

Recovery of silica from from rice straw and husk. p. 411-433. In: Varjani, S., P. Ashok, G. Edgard, K.K. Samir and R. Sindhu (eds.) Chapter 21, Current Developments in Biotechnology and Bioengineering: Resource Recovery from Wastes. Elsevier, Amsterdam, https://doi. org/10.1016/B978-0-444-64321-6.00021-5

Prihartini, I. and V.A. Hariska, V.A. 2019. The effect of suplementing lignolitic probiotic in rice straw on in vitro gas production, contration of ammonia $\left(\mathrm{NH}_{3}\right)$ and volatile fatty acids (VFA). Int. J. Eng. Technol., 8(1.9) 139-143.

Prihartini, I. and K. Khotimah.2011. Lignochloritic bacteria-based rumen probiotic production and its application in dairy cattle. Gamma, 7(1): 27-31.

Prihartini, I., Soebarinoto, S. Chuzaemi and M. Winugroho. 2009. Nutrient characteristic and fermented rice straw degradation by lignolitic TLiD and BOpR inoculums. Anim. Prod., 11(1): 17.

Raabis, S., W. Li and L. Cersosimo. 2019. Effects and immune responses of probiotic treatment in ruminants. Vet. Immunol. Immunopathol., 208: 58-66. https://doi.org/10.1016/j. vetimm.2018.12.006

Rabelo, C.H.S., F.C. Basso, E.C. Lara, L.G.O. Jorge, C.J. Harter, L.J. Mari and R.A. Reis. 2017. Effects of Lactobacillus buchneri as a silage inoculant or probiotic on in vitro organic matter digestibility, gas production and volatile fatty acids of low dry-matter whole-crop maize silage. Grass Forage Sci., 72(3): 1-11. https:// doi.org/10.1111/gfs.12273

Saad, M .J., C.H. Chia, S. Zakaria, M.S. Sajab, S. Misran, H.A. Rahman, and S.X. Chin. 2019. Physical and chemical properties of the rice straw activated carbon produced from carbonization and $\mathrm{KOH}$ activation processes. Sains Malaysiana, 48(2): 385-391. https://doi. org/10.17576/jsm-2019-4802-16

Shah, T.A., C.C. Lee, W.J. Orts and R. Tabassum, 2018. Biological pretreatment of rice straw by Ligninolytic bacillus sp. strains for enhancing biogas production. Environ. Prog. Sustain. Energy, 38(3): 1-9. https://doi.org/10.1002/ ep. 13036

SPSS. 2012. IBM SPSS statistics for windows, version 21.0. Armonk, IBM Corp., New York, USA. 
Yogi, R.K., S.S. Thakur, M. Mohini, S.K. Singh, replacing oil cakes in concentrate mixture. and T. Malik. 2017. In vitro evaluation of Indian J. Anim. Nutr. 34(2): 163-168. https:// concentrate mixtures containing incremental doi.org/10.5958/2231-6744.2017.00028.7 level of rice dried distillers grain with solubles 